\title{
UNGKAPAN DALAM NASKAH BOCCO TALLU ETNIK MANDAR: KAJIAN SEMANTIK
}

\author{
Wahyuddin*
}

\begin{abstract}
This study used the qualitative descriptive method. The data was collected through observation and interview. The data was analyzed through coding and reducing. The researcher interviewed the cultural observer and drew the conclusion of manuscript contribution aspects. The result is as follows. First, the analysis of manuscript discourse aspects was observed with two methods, linguistic and structural methods. The linguistic aspect consist of, intentionality, and acceptability of Bocco Tallu manuscript. The structural method consist of Words, phrases, sentences, stanzas. Second, the analysis of social cultural context of Bocco Tallu manuscript consist of social level (class social), traditional marriage, leadership concepts, arts, and religious system of Mandar tribe. Third, social cultural context of Bocco Tallu manuscript gave contribution to harmonious society in social life of Mandar tribe that is signed with ceremony performed once four years in the presence of all public figures and no other nobles. Having done some analyzes on this text shows the phrases that lead to the concept of power and history in Mandar, especially the kingdom of Alu, Tara Manu 'and Sendana.
\end{abstract}

Keywords: manuscripst, bocco tallu, semantic

\section{PENDAHULUAN}

Naskah merupakan benda yang dijadikan ruang untuk menuangkan dan mencatat semua kejadian masa lampau yang terjadi di masyarakat. Naskah tersebut bukanlah suatu uraian-uraian dan ungkapan kosong atau khayalan yang sifatnya sekadar menghibur pembaca tetapi melalui naskah ini dihidupkan pembaca menjadi lebih arif dan bijaksana dalam bertindak dan berpikir. Salah satu naskah yang memuat nilai kearifan adalah naskah Bocco Tallu (BT).

*) Prodi Pendidikan Bahasa Indonesia, Universitas Al Asyariah Mandar E-mail: Wahyuddin.sendana@yahoo.com 
Menurut sejarah naskah ini memuat informasi yang perlu digali dan dikaji agar dapat diketahui oleh generasi berikutnya. Naskah BT sebagian tidak punya makna tersendiri di kalangan masyarakat, khususnya di Mandar dan juga sudah banyak opini berbeda penafsiran yang terdapat dalam naskah tersebut baik tentang sejarah maupun makna. BT merupakan warisan nenek moyang yang turun-temurun kepada anak cucu masyarakat Mandar yang keberadaannya harus diketahui baik dari segi sejarahnya maupun maknanya.

Kurangnya kerjasama antarkerajaan sehingga masyarakat Mandar mengadakan pertemuan atau perjanjian. Dengan adanya Pertemuan setiap perwakilan kerajaan sehingga muncullah pemikiran raja-raja dan mara'dia untuk berinisiatif membuat kesepakatan dalam bentuk naskah. Itulah yang disebut dengan naskah BT. Penggunaan bahasa dalam naskah diketahui dan disepakati oleh setiap kerajaan, yakni kerajaan Alu, Tara Manu' dan Sendana. Perjanjian ini dikenal dengan nama perjanjian $B T$ yang merupakan perjanjian persekutuan pertama kali di Mandar yang terjadi pada sekitar abad IX/X Masehi. Istilah $B T$ sendiri terdiri dari kata bocco dan tallu dengan pengertian harfiah, yaitu bocco berarti 'kumpulan' dan tallu berarti 'tiga'. Jadi, BT adalah persekutuan atau kumpulan dari tiga kerajaan.

Chaer dan Djadjasudarma (2002), ilmu semantik adalah ilmu ynag mempelajari hubungan antara tanda-tanda linguistik dengan hal yang ditandainya, dan disebut juga ilmu tentang makna atau arti. Sehubungan dengan teori di atas dapat didasarkan pada konsep langue dari Saussure sehingga dapat dimengerti bahwa naskah $B T$ memiliki abstraksi sistem bahasa yang mendasari ungkapan-ungkapan yang penuh makna. Fananie (2000), untuk mengetahui keseluruhan makna dalam sebuah karya sastra, maka unsur-unsur tersebut harus dihubungkan satu sama lain

Sistem tersebut mengarahkan penulis untuk mengatur hubungan konsep imaginer dari citra ungkapan yang terpilih dan terpilah ke dalam tatanan struktur. Dalam ilmu semantik terdapat beberapa hal yang perlu dikaji terutama terletak pada maknat. Makna menjadi bagian dari bahasa, maka semantik merupakan bagian dari linguistik yang mempelajari tentang tandatanda linguistik dengan hal-hal yang ditandainya baik secara lisan maupun tulisan. Pembaca akan lebih jelas memahami makna pada naskah $B T$ yang disajikan ketika ungkapan dalam naskah tersebut diuraikan dengan jelas.

Naskah merupakan satuan bahasa yang lengkap, naskah itu mengandung konsep, gagasan, pikiran, atau ide yang utuh, yang dapat dipahami tanpa keraguan apa pun. Untuk mengungkap makna perbait dalam ungkapan naskah tersebut maka dibutuhkan analisis pertama, analisis pada aspek 
ungkapan naskah ditinjau atas dua macam pendekatan, yaitu pendekatan linguistik teks dan pendekatan structural, intensionalitas, dan akseptabilitas naskah.

Selanjutnya, analisis struktural naskah terdiri atas kata, frasa, ungkapa dan kalimat. Kedua, analisis pada aspek konteks sosial budaya dalam naskah terdapat konsep budaya strata sosial, konsep kepemimpinan, Ketiga, konteks sosial budaya dalam naskah tersebut memberikan kontribusi terhadap terciptanya keselarasan dan keharmonisan dalam kehidupan bermasyarakat orang Mandar, yang ditandai dengan keberadaan naskah $B T$ di setiap kerajaan dan diatur berdasarkan kesepakatan raja atau Mara'dia setempat.

Teeuw (2003), menyatakan analisis struktural bertujuan untuk membongkar dan memaparkan secara cermat, semendetail dan mendalam mungkin keterkaitan dan keterjalinan semua analisis aspek karya sastra yang bersama-sama menghasilkan makna menyeluruh. Ratna (2004), Dalam kajian struktural, karya sastra harus dipandang sebagai suatu struktur yang berfungsi. Arzaki dkk (2001), bahwa kearifan tradisional atau kearifan budaya (local knowledge atau local indegenous) adalah semua keahlian dan pengetahuan yang dimiliki oleh masyarakat tradisional di daerah. Koentjaraningrat (2005), menyatakan manusia dapat berjalan karena kemampuan untuk berjalan itu didorong oleh nalurinya dan terjadi secara alamiah.

Handayani (2010), meneliti Tinjauan Semantik Ungkapan pada Bungkus Permen Kis Mint Barley. Hasil dari penelitian ini adalah makna ungkapan yang terdapat pada bungkus permen kis mint barley di antaranya (1) makna perintah, (2) makna ajakan atau seruan, (3) makna permintaan, (4) makna larangan, (5) makna pertayaan, (6) makna peringatan, dan (7) makna pernyataan.

Penelitian ini bertujuan untuk mendeskripsikan ungkapan naskah Bocco Tallu dalam hal tes naskah, struktur naskah, konteks sosial budaya dalam naskah, dan kontribusi konteks sosial budaya terhadap kearifan masyarakat Mandar masa kini.

\section{METODE PENELITIAN}

\section{Jenis Penelitian}

Penelitian ini merupakan penelitian deskriptif-kualitatif yang mengutamakan kajian semantik. Penelitian kebahasaan deskriptif kualitatif bertujuan mengungkap fakta, keadaan, fenomena, variabel dan keadaan yang terjadi selama berjalannya penelitian dengan berdasar pada keadaan yang apa adanya di lapangan. 


\section{Lokasi Penelitian}

Penelitian ini dilaksanakan di Kabupaten Majene dan Polman (Mandar). Keseluruhan wilayah di Sulawesi Barat merupakan populasi dalam penelitian ini. Sedangkan, penarikan sampel penelitian khusus (Kec. Alu', Tara Mnu' dan Sendana).

\section{Sumber Data}

Sumber data atau informan dalam penelitian ini adalah Mara'dia, Maradia tersebut selaku penyimpan naskah Bocco Tallu dan orang-orang yang mengetahui dan menguasai masalah secara mendalam dan terlibat langsung dengan masalah penelitian. Mengingat metode yang digunakan adalah penelitian kualitatif yang erat kaitannya dengan faktor kontekstual, maka penarikan dilakukan secara purposive sampling. Dalam artian jumlah sampling sudah ditentukan secara khusus berkaitan dengan keabsahan data, sekaligus memeroleh informasi sebanyak mungkin terkait teori yang menjadi dasar penelitian.

\section{Teknik Pengumpulan Data}

Penelitian ini menggunakan teknik pengumpulan data primer dan data sekunder. Data primer berupa observasi langsung untuk memperoleh berbagai informasi dan data faktual serta memahami situasi dan kondisi obyek penelitian. Pengumpulan data tersebut dilakukan dengan penyimakan, wawancara. Penyimakan dilakukan dengan cara menyimak setiap ungkapan yang memiliki unsur-unsur keterpaduan dan hubungan terhadap naskah. Data yang telah terkumpul dicatat kenudian diseleksi, dipaparkan, dan dianalisis sesuai dengan metode analisis.

\section{Metode Analisis Data}

Kategorisasi digunakan sesuai dengan pendapat Moleong (2007), bahwa kategorisasi merupakan penyusunan data untuk membuat coding (pengodean). Keseluruhan data diklasifikasikan berdasarkan lokasi penelitian, unsur makna ungkapan naskah Boco Tallu di Mandar. 2) Penyajian data (Data display). Data yang diperoleh dari informan berupa rekaman ditranskripsi kemudian diuraikan. 3) Penarikan simpulan (Conclusion). 


\title{
HASIL PENELITIAN
}

\section{Struktur Tekstual dalam Naskah BT}

Penelitian ini akan mendeskripsikan bentuk struktur tekstual naskah BT. Pendeskripsian yang dilakukan pada tekstul naskah tersebut, bertujuan untuk memahami makna isi naskah yang orientasinya tidak terlepas dari konteks naskah. Naskah BT tampak adanya bentuk dan struktur tekstualnya dua perjanjian. Perjanjian pertama meliputi empat butir. Sementara perjanjian kedua hanya ada satu butir. Perjanjian ke dua ini, hanya sebagai penguatan pada perjajian pertama. Di samping itu, Sturktur tekstual naskah tersebut meliputi pembukaan, isi, dan penutup. Untuk lebih jelasnya dapa dilihat pada penjelasan di bawah ini:

\section{a. Perjanjian Pertama}

1) Pembukaan (butir pertama) struktur tekstual naskah

Pembukaan pada struktur tekstual naskah berisi tentang himbauan dan sanksi.

Madzondong duang bongi anna' dziang mappasisala Pattallumboccoang, ongani balimbunganna baoangi arianna. Iya-iyannamo tau mambue' puraloa meppondo' diallewuang di Pattallumboccoang mendaung ra'bas, metta'e sape', pappang naola pappang ra'ba, buttu naola buttu latta, puppus sorokawu mangandeapi dipennannaranna tomamboe' pura loa.

Artinya, suatu saat bila ada yang memecah belah persekutuan Bocco Tallu, balikkan bubungan rumahnya ke bawah dan tiangnya ke atas. Barang siapa diantara kita menginkari perjanjian membelakangi kesekapatan dalam persekutuan Bocco Tallu, berdaun gugur bertangkai jatuh, berbatang tumbang berakar putus, dahan dipegang dahan jatuh, lembah dilalui lembah runtuh, gunung dilewati gunung terpotong. Hidupnya terkutuk bagai api membakar turun temurun yang ingkar pada perjanjian.

\author{
Madzondong duang bongi anna' dziang mappasisala \\ Pattallumboccoang, 'besok' 'dua' 'malam' 'jika' 'ada' \\ 'memisahkan' 'bertiga penuh' \\ ongani balimbunganna baoangi arianna. \\ 'balikkan' 'bubungan rumahnya' 'ataskan' 'tiangnya'
}

Iya-iyannamo tau mambueq pura loa meppondoq diallewuang 
'Ia' 'diantara' 'orang' 'membangunkan 'habis' 'ucapan' 'membelakangi' 'lingkaran'

diPattalummboccoang, mendaung ra'bas, metta'e sape', pappang naola

dibertiga penuh, 'berdaun' 'runtuh' 'bertangkai' 'jatuh' 'limbah' 'lalui'

pappang ra'ba, buttu naola buttu latta, puppus sorokawu mangande api 'limbah' 'roboh', 'gunung' 'lalui' 'gunung' retak, 'habis' 'kaput' 'terbakar' 'api'

dipennannarannatomamboe, pura loa.

'diketurunan' 'orang membelakangi' 'habis' 'ucapan'

Pembukaan pada struktur tekstual naskah berisi tentang himbauan dan sanksi. Hal ini terbukti dengan adanya ungkapan.

Madzondong duang bongi anna' dziang mappasisala

Pattallumboccoang, 'besok' 'dua' 'malam' 'jika' 'ada'

'memisahkan 'bertiga penuh'

ongani balimbunganna baoangi arianna.

'balikkan' 'bubungan rumahnya' 'ataskan' 'tiangnya'

Ungkapan ini merujuk kepada penghasut kerajaan berupa sanksi untuk dibalikkan bubungan rumahnya bagi mereka yang tidak setia pada perjanjian. Namun, dalam konteks naskah bubungan rumah dapat dimaknai kepala penghasut kerajaan. Artinya seorang penghasut akan dibalikkan badannya untuk kepalanya di bawah dan kakinya di atas.

2) Isi (butir kedua) struktur tekstual naskah

Isi struktur tekstual dalam naskah tercantum adanya panyatuan prinsip. Berikut data tentang penyatuan prinsip dalam tekstual naskah. 
Nauamo Daeng Palulung: "Tallumi tau anna mesa, mesami anna tallu, Sendana, Alu, Tara Manuq. Litaq silambang tassipomalla, tassitundang matadzang tassiroyong masandeq, tautta sisolong tassisawaq. Mesa balami tanni atonang, Sendana, Alu, Tara Manuq di Puang di Kondo Budata, mate simateang tuo sotuoang".

Artinya, berkatalah Daeng Palulung ; "Kita bertiga telah jadi satu, satu tapi tiga, Sendana, Alu, Taramanuq. Pemimpin saling menyeberang tak keberatan, tak saling mengingatkan dengan keras apalagi kasar, rakyat saling mengunjungi dengan aman. Kita sudah satu pagar tak terbatas, Sendana, Alu, Tara manu' bagi pemimpin dan bagi rakyat. Mati satu mati semua, hidup satu hidup semua".

Nauamo Daeng Palulung: Tallumi tau annaq mesa, Berkatalah Daeng Palulung: 'bertiga' 'orang' 'dengan' 'satu',

mesami annaq tallu, Sendana, Alu, Tara Manuq.

'sudah satu' 'dengan' 'tiga' Sendana, Alu', Tara Manu'.

Litaq silambang tassipomalla, tassitundang matadzang 'tanah' 'menyebrang' 'tidak saling khawatir', 'tidak saling membangunkan' 'tajam'

Tassiroyong masandeq, 'tauttaq' sisolong tassisawaq.

'tidak saling membangunkan'runcing', 'masyarakat kita' 'bersatu'

'tidak saling kebaratan'

Mesa bala tanni atonang. Sendana, Alu' Tara Manu'.

'satu' pagar' 'tidak' 'lingkungan' 'Sendana', 'Alu', 'Tara Manu'

Mate simateang tuo sattuoang.

'mati' 'bersama' 'hidup' 'bersamau'

Salah satu ungkapan penyatuan prinsip di atas antara lain. Berikut data tentang penyatuan prinsip dalam tekstual naskah.

Tallumi tau annaq mesa,

'bertiga' 'orang' 'dengan' 'satu',

mesami annaq tallu, Sendana, Alu, Tara Manu'.

'sudah satu' 'dengan' 'tiga' Sendana, Alu', Tara Manu'. 
Ungkapan ini merupakan ungkapan Daeng Palulung atau raja yang bertugas di Tara Manu'. Maksud ungkapannya adalah ketiga kerajaan sudah dalam satu ikatan perjanjian dan mempunyai visi dan misi yang sama.

3) Penutup (Butir ketiga) struktur tekstual naskah

Isi atau butir struktur tekstual ketiga ini juga menyangkut tentang penyatuan prinsip. Berikut data tentang penyatuan prinsip dalam struktur tekstual naskah.

Nauamo Puatta I Saragiang: "Mammesa puammi tau mammesa tau, maqjuluq sara maqjuluq rio, mammesa pattuju dilatte sallambar siola paqdisang. Da'dua memmata di sawa, mesa memmata di mangiwang, monasisara' tubhu anna nyawa tassisaraqi Alu, Tara Manuq, Sendana. Tassipaoro di adzaq, sipalete di rapang, padza nipeadza' adza'ta, padza niperapangi rapatta', tasibore-boreang gauq tassipolong tanjeng, tassiraqba tanang-tanang, sitaiang apiangan tassitaiang adzaeang".

Artinya, berkatalah Puatta di Saragiang; "Bangsawan kita sudah menyatu rakyat juga jadi satu menghadapi kesusahan dan kebahagiaan, menyatukan keinginan di atas selembar tikar sebantal bersama. Dua mengawasi ular (musuh dari darat/hutan) yang satu mengawasi ikan hiu (musuh dari laut). Walau terpisah tubuh dengan nyawa, tapi Alu, Taramanuq dan Sendana tidak akan terpisahkan. Tidak saling mencampuri urusan adat dan aturan masingmasing, menjalankan adat dan kebiasaan serta hukum dan peraturan masingmasing, tidak saling keras mengerasi, tidak saling merusak tanaman, saling membawa pada kebaikan, saling menghindarkan dari keburukan".

Nauwamo Puatta Saragiang: Mammesa puammi
mammesa tau.
'berkatalah' 'Puang Saragiang: 'bersatu; 'sudah Tuhan' 'orang'
'bersatu' 'orang'

Maqjulu sara ma'julu rio. Mammesa pattuju dilatte sallambar 'mendorong' 'masalah' 'mendorong' 'gembira' 'bersatu' 'ikat' 'ditikar' 'selembar'

siola pa'disang.

'bersama' 'bantal' 
Da'dua memmata di sawa, mesa memmata di mangiwang.

'Dua' 'bermata' 'ular sawa', 'satu' 'bermata' 'di ikan hiu' Monasisara' tubhu anna' nyawa tassisara'i Alu, Tara Manu', Sendana.

'Biar terpisah' 'tubuh' 'dengan' 'nyawa' 'tidak terpisah' Alu' 'Tara Manu' 'Sendana'

Tassipaoroq diadzaq sipalete dirapang,

'Tidak memalukan diada' 'saling menginjak' 'diri masing-masing',

padza nipeadza' adza'ta, padza diperapang rapatta

'gunakan' 'diperadatkan' 'adat masing-masing' 'gunakan' 'seperti' 'diri masing-masing'

Tassibore-boreang gau' tassipolong tanjeng.

'tidak ada dusta' 'perlakuan, 'tidak saling terpotong 'menyinggung'

Tassira'ba tanang-tanangan, sitaiang apiangan, tassitaiang adzaeang.

'tidak runtuh' 'tanaman', 'saling mencari kebaikan', 'tidak saling

keburukan'

Salah satu ungkapan yang menyangkut tentang penyatuan prinsip data di atas adalah.

Nauwamo Puatta Saragiang: Mammesa puammi tau mammesa tau.

'berkatalah' 'Puang Saragiang: 'bersatu; 'sudah Tuhan' 'orang' 'bersatu' 'orang'

Ma'julu sara ma'julu rio. Mammesa pattuju dilatte sallambar 'mendorong' 'masalah' 'mendorong' 'gembira' 'bersatu' 'ikat' 'ditikar' 'selembar'

siola pa'disang.

'bersama' 'bantal' 
Maksud ungkapan di atas adalah bangsawan kita sudah menyatu dengan rakyat, kesusahan dan kebahagiaan merupakan milik bersama. Ketiga kerajaan tidak saling mencampuri adat, tidak saling keras, saling mengingatkan pada kebaikan, menghindari kesalahapaman antara ketiga kerajaan serta tidak ada batas untuk saling mengunjungi satu sama lain.

\section{4) Isi (Butir keempat) struktur tekstual naskah}

Penutup struktur tekstual keempat ini merupakan unsur kepatuhan terhadap hukum dan aturan. Berikut ungkapan tentang kepatuhan terhadap hukum dan aturan.

Nauwa bomo Daeng Palulung: Mate arawiang Alu Tara Manuq, mate di baya-bayai Sendana. Sara pole sara nisolai, leqboq tanni jori', uwai tanni latta, buttu tanni polong dilalanna Bocco Tallu.

Artinya, berkata lagi Daeng Palulung; "Bila Alu dan Tara Manuq mati di sore, Sendana mati di waktu pagi. Kesusahan yang datang kesusahan dibagi, kebahagian yang datang kebahagiaan yang kita bagi. Laut tidak kita garis, air tidak kita putus, gunung tidak kita potong di dalam wilayah Bocco Tallu".

Nauwa bomo Daeng Palulung: Mate arawiang Alu, Tara Manu',

Berkata' 'lagi' 'Daeng' 'Palulung': 'mati' 'sore', 'Alu', 'Tara Manu'

Mate di baya-bayai Sendana,

'Mati' 'di pagi-pagi' 'Sendana'

Sara pole sara nisolai, lebo'tannijori',

'Masalah' 'datang' 'masalah' 'milik bersama' 'laut' 'tidak' 'digaris'

uwai tanni latta, buttu tanni polong dilalanna Bocco Tallu. 'Air' 'tidak' 'retak', 'gunung' 'tidak' 'potong' 'di dalamnya' 'kerajaan' 'tiga'

Salah satu ungkapan yang menyangkut tentang kepatuhan terhadap hukum dan aturan. Hal ini ditandai pada ungkapan. 


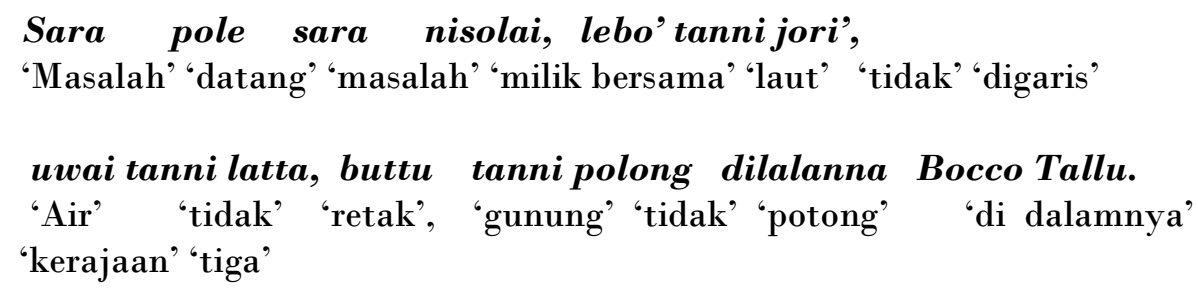

Makna ungkapan tersebut, ketiga kerajaan sudah sepakat bahwa kesusahan dan kebahagiaan merupakan tanggung jawab bersama. Hukum dan aturan dijalankan masing-masing.

\section{b. Perjanjian Kedua}

\section{1) Isi (Butir Pertama) struktur tekstual naskah}

Selanjutnya butir partama bagian dari perjanjian kedua. Perjanjian kedua ini tercantum hanya satu butir. Isi pada perjanjian kedua ini berupa penguatan. Maksud pada penguatan tersebut untuk lebih mempertegas pada pejanjian pertama.

Nauamo Puatta Isa' Adawang di Puanna I Lepong Puang di Galu-galung: sitai' mattallumbocco, mammesa puang mammesa tau, massambua litaq, mammesa pa'disang, massambua tallo'. Tassipasau tassipale'mai, tassiboreboreang gau'. Anna iya-iyannamo namappasisala pattallumboccoang, tammeari tammennannar, ma'bulu pindang tama'bulu pendiboeanna. Anna iya-iyannamo tau mangipi ma'uwa; iyamo dilalang di'e diwattangan tommuane napakkira-kira namappasisala pamboccoang, sirumunni'-i mattallumbocco anna mappadziang elo', anna' disesse'i dianusang di uwai tammembali. Maloli'mi tallo' di atambusang tarruppu tammammar, tammangapa. Mesa memmata di mangiwang da'dua memmata di sawa. Maui lambi' naung Sumakuyu manguma pandudzung pandengnge'na litaq di Alu, andiang ulawa-lawai. Anna mua' diang mambore-borei tandi adza' tandi rapang, tania tu'-u litaq di Alu nabore', litaq di Sendana tu'-u. Tettoi tia Sendana, maui lambi' tama Ratte Matama pandudzung pandengnge'nalitaq di Sendana manguma andiang ulawa-lawai, anna mua diang ubore-borei tandi rapang tandi adza', tania tu'-u lita di Sendana nabore', litaq di Alu tu'-u. Apa' sikira-kirai diapiangan tassikira-kira di adzaeang. Tassipolong tanjingngi', tassira'ba tanattanani', tassipeleiang 
puraloa. Anna madzondong duambongi anna silambi' pakke barangbarangag, dai' situndang, dai siroyong tallotang. Sipatuppi' diadza'sipaletei dirapang.

Artinya, maka berkata Puatta Isaq-Adawang pada Puanna I Lepong, Puang I Galu-galung: Kita bertemu tiga kerajaan yang bersekutu, untuk bersatu pemerintah, bersatu rakyat bersatu negeri, bertikar selembar sebantal bersama, berbulat telur. Tidak saling kesana kemari, tidak saling memperlihatkan tabiat tidak terpuji. Siapa saja yang ingin memisahkan persekutuan Bocco Tallu, mereka beranak tak berkepala, berbulu piring tak berbulu keturunannya, dan barang siapa yang bermimpi mengatakan; inilah anak laki-laki yang saya kandung akan memecah belah Bocco Tallu sesudah lahir kelak, adakan musyawarah tiga kerajaan yang bersekutu untuk segera membedah orang hamil tersebut lalu keluarkan anak yang dikandungnya kemudian hanyutkan di air tak kembali. Telur terguling kearah matahari terbit, tak pecah tak memar, tak apaapa. Satu mengawasi ikan Hiu, dua mengawasi ular. Biar sampai ke Sumakuyu masyarakat Alu berkebun, tidak akan ada yang menghalangi. Kalau ada yang melarang tidak sesuai hukum dan aturan serta adat kebiasaan, maka bukan orang Alu' yang dihalanginya tapi orang Sendana. Begitu juga Sendana, biar sampai ke Ratte Matama berkebun tidak akan ada yang menghalangi tidak sesuai hukum dan peraturan. Maka bukanlah orang Sendana yang dihalangi tapi melainkan orang Alu. Karena kita saling menuntun pada kebaikan dan saling menghindarkan dari keburukan. Tidak saling keras mengerasi, tidak saling merusak tanaman, tidak saling ingkar dari kesepakatan. Besok lusa bila pernah berkongsi harta jangan saling menagih dengan keras dan tajam. Mari kita saling menghormati hukum, saling mematuhi aturan.

Nauamo Puatta Isa' Adawang di Puanna I Lepong Puang di Galugalung:

'Berkatalah'

sitai mattallumbocco, Mammesa Puang mammesa tau.

'saling' 'bertemu bertiga kerajaan' 'bersatu' 'Tuhan' 'bersatu' 'orang'

Massambua litaq, mammesa pa'disang, massambua talloq. 'bersatu buah' 'tanah', 'bersatu' 'bantal', 'bersatu butir' 'telur'

Tassipasau tassipaleqmai, tassibore-boreang gauq. 
'Tidak saling ke sana' 'tidak saling ke sini', 'tidak salingtersinggung perlakuan'.

Anna iya-iyannamo namappasisala pattallumboccoang, tammeari 'Jika' 'di antara kita' 'memisahkan' 'bertiga kerajaan', 'tammeari'

Tammennannar. Maqbulu pindang tama'bulu pendiboeanna. 'Tidak tangguh', 'berbulu' 'piring' 'tidak berbulu' 'di luarnya' Annaq Iyamo tau mangipi mauwa iyamo di lalang diq-e 'Jika' 'itulah' 'orang' 'bermimpi 'berkata' 'inilah' 'di dalam' 'ini'

diwattangang tommuane napakkira-kira namappasisala Pamboccoang.

'Dikehamilan' 'laki-laki' 'berencana' 'akan memisahkan' 'kerajaan'

Sirumunniq-i mattallumbocco anna' mappadziang eloq, annaq disesseqi 'krumunilah', 'bertiga bokko' 'dengan' 'mengadakan' 'mau' 'dengan' 'bedahla'

dianusang di uwai tammembali.

'hanyutkan' 'di air' 'tidak kembali'

Maloliqmi talloq di atambusang tarruppu tammammar, tammangapa.

'Tergulinglah' 'telur' 'dit barat' 'tidak hancur' 'tidak memar'

'tidak apa-apa'

Mesa memmata di mangiwang, da'dua memmata di sawa 'Satu' 'punya mata' 'di ikan' 'Hiu', 'dua' 'punya mata' 'di Ular'

Maui lambi naung Sumakuyu manguma pandudzung pandengngeqna litaq 'Biar' 'sampai' 'turun' 'Sumakuyu' 'berkebun' 'menjinjing' 'gendongannya' 'tanah'

di Alu, andiang ulawa-lawai.

di Alu', ' tidak ada' 'kuantarai'

annaq mua diang mambore-borei tandi adza'q tandi rapang, tania tu'u litaq

'jika' 'kalau' 'ada' 'mengganggu-ganggu'tidak' 'adat', 'tidak' 'diri', 'bukan' 'itu' 'tanah' 
Di Alu nabore, litaq Sendana tuq-u

'Alu' 'diganggu', 'tanah' 'Sendana' 'itu'

Tettoi tia Sendana, maui lambiq tama Ratte Matama pandudzung

'Begitu' ‘juga' 'Sendana', 'biar' 'sampai' 'masuk' Ratta Matama 'penginjing'

pandengngeqna itaq di Sendana manguma andiang ulawa-lawai, anna' mua 'gendongannya' 'tanah' 'di sendana' 'berkebun' 'tidak ada' 'antara 'dengan' 'jika'

diang ubore-borei tandi rapang tandi adza', tania tu'-u lita di Sendana

'ada' 'belakang-belakangi' 'misalnya' 'tidak adat', 'bukan' 'itu' 'tanah' 'di Sendana'

naboreq, litaq di Alu tuq-u.

'dibelakangi', 'tanah' 'di Alu' 'itu'

Apaq sikira-kirai diapiangan tassikira-kira diadzaeang.

'Karena' 'saling' 'dikebaikan' 'tidak' 'saling' 'dikeburukan'

Tassipolong tanjingngi, tassira'ba tanattanani', tassipeleiang pura

loa.

'Tidak saling tajam', 'tidak saling runtuh tanaman', ‘tidak saling tinggal' 'habis' 'ucapan'

Anna' madzondong duang bongi anna'silambiq pakke barang-

barangang,

'jika' 'besok' 'dua' 'malam', 'jika' 'bertemu' 'harta'

dai' situndang, dai' siroyong tallotang

'naik' 'saling membangunkan', 'naik' 'menggoyang' 'tidak tempat'

Sipatuppiq diadzaq sipaletei dirapang.

'Saling bertahan' 'diadat' 'saling menginjak' 'diri masing-masing'

Isi perjanjian kedua di atas, memuat beberapa ungkapan yang merupakan pengulangan ungkapan pada perjanjian pertama. Sehingga, maksud dan tujuan perjanjian pertama dan kedua mempunyai asumsi yang sama. Salah 
satu ungkapan yang menyangkut tentang kepatuhan terhadap hukum dan aturan. Hal ini ditandai pada ungkapan.

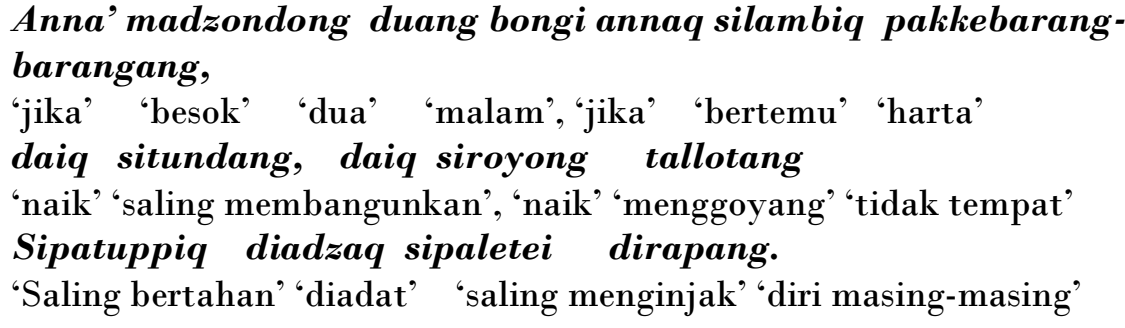

Artinya, jika besok lusa bila pernah berkongsi harta jangan saling menagih dengan keras dan tajam. Mari kita saling menghormati hukum, saling mematuhi aturan.

Makna pada ungkapan tersebut, dapat dimaknai bahwa jika ada salah satu diantara ketiga kerajaan yang bertikai tentang utang, harta maupun sejenisnya. Maka, janganlah menagih secara kasar apalagi tidak sesuai dengan ketentuan adat

\section{PEMBAHASAN}

Penelitian ini menemukan naskah Perjanjian $B T$ dibentuk untuk membangun satu kekuatan dengan melihat situasi dan kondisi di Mandar pada saat itu. Sangat jelas dalam butir kesepakatan bahwa pertahanan dan keamanan merupakan prioritas utama disamping kerjasama disetiap wilayah. Ini merupakan salah satu upaya untuk mencegah terjadinya perang saudarah antara Sendana, Seiring dengan waktu naskah ini sudah di perbaharui dengan modernisasi dalam bentuk buku yang sebelumnya ditulis lontara, naskah ini dapat kita temukan diperpustakaan umum Majene, yaitu di Assamalewuang. Bentuk aslli naskah ditulis di daun Lontara sebanyak 3 buah lilitan, setiap lilitan terdapat sembilan meter dan lebar dua $(\mathrm{cm})$. artinya tiga buah lilitan tersebut melambangkan ketiga kerajaan yaitu kerajaan Alu, Tara Manu' dan Sendana. Setiap buah terdapat beberapa bait, setiap bait terdapat makna denotasi dan konotasi, menurut narasumber (Mara'dia) atau sumber data, naskah tersebut akan bermakna sesuai dengan konteks naskah jika kita memilah perbait.

Alu dan Taramanu' yang bisa saja terjadi akibat hasutan dan strategi adu domba yang dijalankan oleh orang-orang diluar wilayah Mandar pada saat itu. 
Intensionalitas berhubungan dengan sikap dan tujuan penulis naskah. Teks dibangun dan dirancang berdasarkan tujuan dan maksud tertentu. Naskah $B T$ diciptakan oleh pengarangnya yang sama sekali tidak bisa lepas dari peristiwa. Aspek kehidupan yang diungkapkan dalam naskah mengandung aspek-aspek kejadian masa lalu, bukan individual.

Dalam naskah $B T$, penulis akan memperhatikan ungkapan-ungkapan sehingga ungkapan yang digunakan merupakan ungkapan yang kiasan serta berisikan makna tertentu, untuk diwujudkan menjadi yang penuh makna, naskah $B T$ dalam setiap ungkapan-ungkapan perbait tidak sekadar dipilih begitu saja oleh penulisnya. Satu ungkapan dipilah untuk dipadukan atau dijakstaposisikan terhadap ungkapan lain dalam suatu konfigurasi dari bait ke bait, sehingga membentuk suatu keutuhan cerita yang memiliki pertautan semantis. Dengan demikian, dari pertautan tersebut diperolehlah makna yang semakin terarah. Makna yang terdapat dalam naskah mencerminkan sebuah kehendak penulis untuk dapat dipahami pembaca.

Akseptabilitas adalah tingkat kesiapan pendengar atau pembaca untuk mengharapkan sebuah teks yang berguna dan relevan. Akseptabilitas atau keberterimaan sebuah teks ditandai dengan kebergunaan dan kerelevanan teks tersebut dalam dunia nyata (real). Akseptabilitas naskah BT merupakan cerminan dari aspek intensionalitasnya. Bukti akseptabilitas naskah dapat dilihat dari beberapa unsur penaskahan dan isi cerita, di antaranya (a) model penyampaian yang bermakna pada masyarakat khususnya ke Tiga Kerajaan yaitu Sendana, Alu, dan Tara Manu'. Ceritera naskah BT diakui dalam upacara yang di adakan sekali dalam empat tahun di masyarakat Mandar, karena ceritera naskah ini milik masyarakat yang disakrarkan kehidupan orang Mandar tempo dulu hingga sekarang, misalnya dalam prinsip pemerintahan, diantranya, jujur, tegas, nasehat.

\section{SIMPULAN}

Berdasarkan hasil analisis yang telah dilakukan pada ungkapan naskah BT disimpulkan bahwa analisis pada aspek ungkapan naskah yang ditinjau atas dua pendekatan analisis, yaitu analisis linguistik dan analisis struktural memberikan pemahaman secara mendalam terhadap keruntutan dan ketergayutan teks naskah, sehingga isi naskah dapat dipahami dengan baik. Analisis aspek linguistik naskah meliputi kata, frasa kalimat, ungkapan. Aspek intensionalitas dan akseptabilitas naskah mencerminkan kebudayaan Mandar pada masanya dengan menggunakan tembang sebagai media komunikasi. Pada aspek akseptabilitas naskah ditandai dengan adanya konteks sosial budaya 
masyarakat Mandar yang meliputi kelas sosial, budaya, kepemimpinan dan lain-lain.

\section{SARAN}

Disarankan kepada pemerintah maupun masyarakat Mandar terkhusus untuk masyarakat Alu, Tara Manuq dan Sendana menerapkan isi naskah tersebut untuk menciptakan keselarasan dan keharmonisan serta membudidayakan mengukuti upacara yang dilaksanakan sekali dalam empat tahun.

\section{DAFTAR PUSTAKA}

Aminuddin. (2010). Semantik: Pengantar Studi Tentang Makna. Bandung: Algasindo.

Chaer \& Djadjasudarma. (2009). Pengantar Semantik Bahasa Indonesia. Jakarta: Rineka Cipta.

Fananie Z. (2011). Telaah Sastra. Surakarta: UMS Press.

Handayani T. (2010). Tinjauan Semantik Ungkapan pada Bungkus Permen Kis Mint Barley. Skripsi. Surakarta: FKIP Universitas Muhammadiyah Surakarta.

Jalaludin A. Dkk. (2013). Kearifan Budaya Sasak dalam Menciptakan Kehidupan yang harmonis. Mataram: Redam.

Koentjaraningrat. (2010). Pengantar Antrophologi 1. Jakarta: Rineka Cipta.

Mandra A.M. (1986). Transliterasi dan Terjemahan Lontara Balanipa Mandar.

Ujung Pandang.

Mandra A.M. (1987), Beberapa Perjanjiian dan Hukum Tradisi Mandar. Yayasan Saqdawang Sendana Majene.

Mandra A.M.. (2001). Kerajaan Sendana. Yayasan Saqdawang Sendana Majene.

Moleong J. (2007). Metodologi Penelitian Kulalitatif. Bandung: PT Remaja Rosdakarya.

Teeuw A. (1984). Sastra dan Ilmu Sastra. Pengantar Teori Sastra. Jakarta: Pustaka Jaya.

Teeuw A. (2009). Sastera dan Ilmu Sastera. Jakarta: Pustaka Jaya.

Yasil S. (2009). Inventarisasi, Transkripsi, Penerjemahan dan Penulisan Latar Belakang isi Naskah Kuno/Lontar Mandar Daerah Sulawesi Selatan, Departemen Pendidikan Kebudayaan Proyek Inventarisasi Dokumentasi Kebudayaan Daerah.

Yasil S. (2011). Ensikopei Sejarah, Tokoh dan Kebudayaan Mandar, lembaga Advokasi dan Pendidikan Anak Rakyat (LAPAR). Yogyakarta. 